\title{
Quantification of the Toxicity of Aqueous Chlorine to Spores of Penicillium digitatum and Geotrichum citri-aurantii
}

\author{
J. L. Smilanick, J. Aiyabei, and F. Mlikota Gabler, USDA Agricultural Research Service, San Joaquin Valley Ag- \\ ricultural Sciences Center, 9611 S. Riverbend Avenue, Parlier, CA 93648, J. Doctor and D. Sorenson, Sunkist \\ Growers 222 W. Lindmore Street, Lindsay, CA 93247; and B. Mackey, Biometrics Unit, USDA ARS, Western Re- \\ gional Research Center, 600 Buchanan Street, Albany CA 94710-1100
}

\begin{abstract}
Smilanick, J. L., Aiyabei, J., Mlikota Gabler, F., Doctor, J., Sorenson, D., and Mackey, B. 2002. Quantification of the toxicity of aqueous chlorine to spores of Penicillium digitatum and Geotrichum citri-aurantii. Plant Dis. 86:509-514.

Chlorine toxicity to Penicillium digitatum and Geotrichum citri-aurantii, causes of green mold and sour rot of citrus, respectively, was quantified. In $3 \% \mathrm{wt} / \mathrm{vol} \mathrm{NaHCO}_{3}$ containing $200 \mu \mathrm{g}$ free chlorine per $\mathrm{ml}$ at $\mathrm{pH} 8.3,95 \%$ of $P$. digitatum spores died $\left(\mathrm{LT}_{95}\right)$ by $180 \mathrm{~s}$ at $5^{\circ} \mathrm{C}$, while only $32 \mathrm{~s}$ were required at $24^{\circ} \mathrm{C}$. The $\mathrm{LT}_{95}$ of G. citri-aurantii arthrospores was 108 and $31 \mathrm{~s}$ at 5 and $24^{\circ} \mathrm{C}$, respectively. Mortality slowed 2- to 4 -fold for each unit of increase from $\mathrm{pH} 7$ to 10. The $\mathrm{LT}_{95}$ of $P$. digitatum spores in $200 \mu \mathrm{g}$ free chlorine per ml at $24^{\circ} \mathrm{C}$ at $\mathrm{pH} 7,8,9$, and 10 was $13.2,19.1,29.4$, and $88.4 \mathrm{~s}$, respectively. The $\mathrm{LT}_{95}$ of G. citri-aurantii at $\mathrm{pH} 7,8,9$, and 10 was 3.0, 12.6, 56.6, and $114 \mathrm{~s}$, respectively. Models were prepared describing mortality. Brief immersion in $200 \mu \mathrm{g}$ free chlorine per $\mathrm{ml}$ reduced viable spores of P. digitatum and G. citriaurantii from $10^{6}$ to $10^{3}$ spores per lemon, and naturally occurring yeast and molds from $10^{6}$ to $10^{4} \mathrm{CFU}$. In fruit wound-inoculated and immersed $24 \mathrm{~h}$ later in water, 4,000 $\mu \mathrm{g}$ free chlorine per $\mathrm{ml}$, or $3 \% \mathrm{wt} / \mathrm{vol} \mathrm{NaHCO}_{3}$, green mold occurrence after storage was $98.5,68.3$ and $7.5 \%$, respectively.
\end{abstract}

Additional keywords: Geotrichum candidum, green mold, sodium bicarbonate, sodium hypochlorite, sour rot

Chlorine is used commonly to sanitize fresh fruit and vegetables during processing after harvest. For citrus fruit, it is used in dump tanks, drenches, and high-pressure fruit washing systems. Recommendations state it should be used at 50 to $200 \mu \mathrm{g}$ free chlorine per $\mathrm{ml}$ and the $\mathrm{pH}$ should ideally be controlled to approximately 7 and should not exceed $8(3-5,9,21,23)$. Chlorine alone at these levels cannot prevent decay after wounds on fruit are inoculated; it kills spores in process water and on the surface of fruit, so that fruit with wounds made before processing are not inoculated when they contact process water (9). Chlorine at these relatively high rates is needed because the time fruit are in contact with the solution is brief, from $15 \mathrm{~s}$ to several minutes, and because fungal spores are comparatively resistant to chlorine and require relatively long periods to die compared to many other microbes (31). For example, Robbs et al. (24) reported cells of

Corresponding author: J. L. Smilanick

E-mail: jsmilanick@aol.com

Accepted for publication 20 December 2001.

Publication no. D-2002-0225-01R

This article is in the public domain and not copyrightable. It may be freely reprinted with customary crediting of the source. The American Phytopathological Society, 2002.
Erwinia carotovora subsp. carotovora 50 times more sensitive to chlorine than conidia of Geotrichum candidum.

First used more than 75 years ago $(2,10)$, sodium carbonate and sodium bicarbonate are in common commercial use to reduce losses by the postharvest citrus diseases green mold $(16,28,29)$, blue mold (19), and sour rot (29), caused by Penicillium digitatum (Pers.:Fr.), P. italicum Wehmer, and G. citri-aurantii (Ferraris) R. Cif. \& F. Cif. ("G. candidum" Link), respectively. These pathogens require wounds for infection to occur (9). The fruit must be immersed in tanks of the solutions for a minute or more (28) or washed with the solution applied at high pressure (30) to obtain the most effective control. Sodium carbonate and bicarbonate reduce the incidence of these diseases (reduction in occurrence of 50 to $95 \%$ ), even when applied $24 \mathrm{~h}$ after inoculation of wounded fruit, they are equally efficacious, and sodium salts were superior to potassium or ammonium salts (29). A significant shortcoming of these solutions is that they are fungistats (14) and can become contaminated with spores of these pathogens and other microbes. Chlorine is often added at $200 \mu \mathrm{g}$ free chlorine per $\mathrm{ml}$ to sodium bicarbonate solutions because it destroys inoculum and other microbes suspended in the solutions, and it slightly but significantly enhances the control of green mold (29).
Although the principles describing chlorine toxicity have long been known (31) and use recommendations developed, studies that quantified the sporocidal activity of chlorine against citrus pathogens are few $(5,9,24)$ and none examined its toxicity when combined with bicarbonate salts. Two aspects of bicarbonate solution, high $\mathrm{pH}$ and ionic strength, can impact chlorine toxicity. As $\mathrm{pH}$ increases, the toxicity of chlorine decreases $(27,31)$. The $\mathrm{pH}$ of sodium bicarbonate solution is high at rates (3\% wt/vol) it is used on citrus fruit (29), about $\mathrm{pH} 8.3$ when freshly prepared, and the $\mathrm{pH}$ increases when solutions open to the atmosphere lose carbon dioxide. The rate of change depends on the surface area of the tank, temperature, and amount of agitation; in some facilities, it can increase to over $\mathrm{pH} 9$ in a day, in others, in about 4 or 5 days. The $\mathrm{pH}$ of sodium carbonate is very high, about 11.5 when freshly prepared, and the $\mathrm{pH}$ declines as the solution accumulates carbon dioxide from the atmosphere. Sodium carbonate is not typically chlorinated commercially because it is anticipated that its very high $\mathrm{pH}$ would render the chlorination ineffective. High ionic strength, a characteristic of these bicarbonate solutions, increases ionization of weak acids such as hypochlorous acid, indicated by a decrease in the dissociation constant $\left(\mathrm{pK}_{\mathrm{a}}\right)$ of about one-half unit, and the reduction in hypochlorous acid content which presumably diminishes chlorine toxicity.

Our objectives were to determine the persistence of chlorine in bicarbonate salt solutions, quantify the impact of temperature and $\mathrm{pH}$ on the toxicity of chlorine to spores of $P$. digitatum and G. citri-aurantii, measure the influence of chlorine treatment on populations of pathogen spores and natural microbe populations on the surface of fruit, and to determine if chlorine at very high rates could control the decay of lemons or oranges after the inoculation of wounds with spores of $P$. digitatum.

\section{MATERIAL AND METHODS}

Culture of pathogens. $P$. digitatum (isolate M6R from J. W. Eckert, University of California, Riverside) was cultured 1 to 2 weeks on potato dextrose agar (PDA). Spores were harvested by adding $5 \mathrm{ml}$ of water containing $0.05 \%$ Triton X-100 to the petri dish, rubbing the surface with a 
sterile glass rod, and passing the suspension through two layers of cheese cloth. The suspension was diluted with water to an absorbance of 0.1 at $425 \mathrm{~nm}$ determined with a spectrophotometer; this density contains about $10^{6}$ spores per $\mathrm{ml}(8)$. $G$. citri-aurantii isolate $99-3$ was similarly cultured and prepared, except the number of arthrospores was determined using a hemacytometer.

Free and total chlorine. The definition of free chlorine we use is the sum of available $\mathrm{HOCl}$ and $\mathrm{OCl}^{-}$; that of total chlorine is the sum of free $\mathrm{HOCl}$ and $\mathrm{OCl}^{-}$plus reversibly combined chlorine that is liberated just before the analysis is conducted (1). To determine chlorine content, $\mathrm{N}, \mathrm{N}$ diethyl-p-phenylenediamine (DPD) was added in excess to the test solutions diluted to contain about $4 \mu \mathrm{g}$ per $\mathrm{ml}$ chlorine and the development of red color measured at $520 \mathrm{~nm}$ with a colorimeter (Model DR 890 or Model Free and Total Colorimeter 46700-00, Hach, Inc. Loveland, CO). For free chlorine determination, in the absence of iodide ion, free chlorine reacted instantly with DPD to produce a red color, which was measured immediately (1). For total chlorine determination, an excess of iodide ion was added, which liberates chlorine from monochloramine, dichloramine, and other substances, and the absorbance was recorded after 2 min. Sodium bicarbonate was diluted sufficiently that it did not interfere with the accuracy of the analysis. The accuracy of the DPD analysis was checked by two methods: (i) by comparison of free chlorine content of a 20 $\mu \mathrm{g} / \mathrm{ml}$ chlorine standard by titration with sodium thiosulphate, and (ii) using a color standard that represented DPD analysis results with $0.2,0.8$, and $1.5 \mu \mathrm{g} / \mathrm{ml}$ chlorine (SpecCheck secondary standards, Hach Co., Loveland, CO). Glassware used in contact with chlorine solutions was made "chlorine demand-free" by soaking it in a $5 \%(\mathrm{vol} / \mathrm{vol})$ solution of laundry bleach $(5.25 \%$ a.i.) in water for $1 \mathrm{~h}$ before use and rinsing it with deionized water $\left(\mathrm{dH}_{2} \mathrm{O}\right)$.

Compatibility of chlorine with bicarbonate salt solutions. The chlorine content of sodium hypochlorite solution (Sigma Chemical Co., Chicago, IL) was determined using DPD colorimetric analysis. Chlorine solution was added to $25 \mathrm{ml}$ of distilled water $\left(\mathrm{dH}_{2} \mathrm{O}\right)$ or $0.5 \mathrm{M} \mathrm{Na}$ $\mathrm{HCO}_{3}, \mathrm{KHCO}_{3}$, or $\mathrm{NH}_{4} \mathrm{HCO}_{3}$ solutions to make a final concentration of $200 \mu \mathrm{g} / \mathrm{ml}$ free chlorine. The $\mathrm{pH}$ of each solution was 8.3 and the temperature was 22 to $24^{\circ} \mathrm{C}$. At intervals of $24 \mathrm{~h}$ for the next $240 \mathrm{~h}$, the free hypochlorite content of each solution was determined by dilution in $\mathrm{dH}_{2} \mathrm{O}$ of a single $0.4 \mathrm{ml}$ aliquot of each followed by DPD analysis. The clear glass containers, which were exposed to ambient light in the laboratory, were opened briefly only to extract the aliquot and resealed. The experiment was conducted twice.
Impact of temperature and $\mathrm{pH}$ on the mortality of spores of $P$. digitatum and G. citrii-aurantii in $\mathrm{NaHCO}_{3}$ and chlorine. To determine the impact of temperature on the mortality of spores, a solution containing final concentrations of $\mathrm{NaHCO}_{3}$ of $3 \% \mathrm{wt} / \mathrm{vol}$ and $200 \mu \mathrm{g}$ free chlorine $/ \mathrm{ml}$ was adjusted to $\mathrm{pH} 8.3$ with $1 \mathrm{~N} \mathrm{HCl}$ or $\mathrm{KOH}$, sealed in an air-tight flask, and incubated at 5 and $24^{\circ} \mathrm{C}$ for $24 \mathrm{~h}$. The spore mortality apparatus and all reagents used resided in a temperature-controlled room where the tests were conducted. To determine the impact of $\mathrm{pH}$ on the mortality of spores at 22 to $24^{\circ} \mathrm{C}$, a solution containing $\mathrm{NaHCO}_{3}(3 \% \mathrm{wt} / \mathrm{vol})$ and $200 \mu \mathrm{g}$ free chlorine/ml was adjusted to $\mathrm{pH} 7.0,8.0$, $8.3,9.0$, and 10.0 with $1 \mathrm{~N} \mathrm{HCl}$ or $\mathrm{KOH}$ just before use in the procedure to quantify the mortality of spores in solutions. Preliminary tests showed that without chlorine the procedure did not reduce the germination of the spores. Each test combination of $\mathrm{pH}$ and temperature was conducted three times.

Mortality of spores in chlorinated solutions. $P$. digitatum and $G$. citri-aurantii were cultured as previously described and suspensions in water containing approximately $10^{6}$ spores per $\mathrm{ml}$ were prepared. A $0.5 \mathrm{ml}$ volume of the spore suspension was dispensed on the surface of a $25 \mathrm{~mm}$ diameter, 3- $\mu \mathrm{m}$ pore size polycarbonate filter clamped in a $25-\mathrm{ml}$ volume glass filter support, which had been fitted into a 1-liter flask with a side arm attached to a vacuum pump. The vacuum was adjusted so the flow of solution through the filter was 1.5 $\mathrm{ml}$ per min. To expose the spores to the test solution, the vacuum was applied briefly to withdraw free water from the spores residing on the filter surface, a 5-ml volume of sterile $\mathrm{dH}_{2} \mathrm{O}$ was added and withdrawn, and the chlorine solution was added and the exposure time initiated. To prevent chlorine reaction products from forming around the spores and modifying the toxicity of the solution, the solution flowed constantly at $1.5 \mathrm{ml}$ per min during exposure of the spores. At the end of the exposure period, $1 \mathrm{ml}$ of $1,000 \mu \mathrm{g} / \mathrm{ml}$ calcium thiosulfate was dispensed to the surface of the filter to reduce the residual chlorine to chloride, followed by two 5-ml volumes of sterile $\mathrm{dH}_{2} \mathrm{O}$, each added when liquid residing on the filter surface had passed through the filter. Preliminary tests showed that calcium thiosulfate did not reduce the germinability of the spores. The filter was removed, added to $10 \mathrm{ml}$ of sterile $\mathrm{dH}_{2} \mathrm{O}$, and agitated at high speed with a reciprocating vortex device. Serial dilutions were prepared and $0.2-\mathrm{ml}$ volumes each were dispensed and spread on duplicate 100mm-diameter petri dishes containing dichloran rose bengal chloramphenicol agar (DRBC, Difco, Chicago, IL). The dishes were incubated at $20^{\circ} \mathrm{C}$ for 5 days, and the number of colonies enumerated. The minimum number of viable spores that could be detected, approximately 5 colonies per plate, was 250 per ml.

Quantification of the mortality of spores and natural microbe populations on the surface of lemon fruit. Four hundred freshly harvested 'Eureka' lemons were randomized, 100 were not cleaned and 300 were rigorously washed with fresh tap water over rotating brushes on a packing line and dried in air. The fruit without prior cleaning were treated with the test solutions, while spores of $P$. digitatum or $G$. citri-aurantii were applied to the cleaned fruit before treatment. P. digitatum and $G$. citri-aurantii were cultured as previously described, suspensions in water containing approximately $10^{7}$ spores per $\mathrm{ml}$ were prepared, and approximately $1 \mathrm{ml}$ of the spore suspension per fruit was applied with a low-pressure air-brush sprayer. The fruit were dried in air and the treatments were applied $24 \mathrm{~h}$ later. Fruit were dipped for $2 \mathrm{~min}$ at $25^{\circ} \mathrm{C}\left( \pm 0.5^{\circ} \mathrm{C}\right)$ into one of the following; (i) buffered $\mathrm{dH}_{2} \mathrm{O}$ alone, (ii) $\mathrm{NaHCO}_{3}(3 \% \mathrm{wt} / \mathrm{vol}$ ) alone, (iii) $50 \mu \mathrm{g}$ free chlorine/ml alone, (iv) $200 \mu \mathrm{g}$ free chlorine/ml alone, (v) $\mathrm{NaHCO}_{3} \quad(3 \%$ $\mathrm{wt} / \mathrm{vol}$ ) with $50 \mu \mathrm{g}$ free chlorine $/ \mathrm{ml}$, and (vi) $\mathrm{NaHCO}_{3}(3 \% \mathrm{wt} / \mathrm{vol})$ with $200 \mu \mathrm{g}$ free chlorine/ml. All solutions contained 25 $\mathrm{mM} \mathrm{KH}{ }_{2} \mathrm{PO}_{4}$ and were adjusted to $\mathrm{pH} 7.7$ before use and the $\mathrm{pH}$ did not change during the test. The treatments were applied to two replicates of 10 fruit each. The treatment solutions, each 10 liter in volume, were contained in a stainless-steel, computer-controlled heated tank system with 12 22-liter-capacity tanks. The solutions were stirred constantly with a 3-cmdiameter propeller revolving at $500 \mathrm{rpm}$. After treatment, the fruit were immediately rinsed for $5 \mathrm{~s}$ with $250 \mathrm{ml}$ of $\mathrm{dH}_{2} \mathrm{O}$ in a low pressure spray and then placed at $1{ }^{\circ} \mathrm{C}$ for no longer than $48 \mathrm{~h}$ before further analysis. To determine the populations of spores or natural microbes, each replicate was sealed inside 4-liter-capacity sterile plastic bags containing $500 \mathrm{ml}$ of $0.1 \%$ peptone and $0.01 \%$ Triton X-100 (each $\mathrm{wt} / \mathrm{vol}$ ), and placed in a reciprocating shaker (displacement $100 \mathrm{~cm}, 100$ cycles per minute). After $20 \mathrm{~min}$, the samples were inverted and shaken for an additional $20 \mathrm{~min}$. Serial dilutions were prepared and 0.2-ml-volumes each were dispensed to duplicate 100-mm-diameter petri dishes containing DRBC or plate count agar (PCA). DRBC dishes were incubated at $20^{\circ} \mathrm{C}$ for 5 days, and colonies of $P$. digitatum, G. citri-aurantii, or "total yeast and molds"(20) enumerated. PCA was incubated at $37^{\circ} \mathrm{C}$ for 2 days and colonies of aerobic mesophilic bacteria (20) enumerated. The experiment was conducted three times.

Green mold on inoculated lemons and oranges after immersion in chlorine or $\mathrm{NaHCO}_{3}$ solutions. Standard methods recommended to evaluate citrus postharvest fungicides were used (8). Lemons and 
oranges used in all experiments were selected by hand from field bins soon after harvest, washed with water, and randomized. A suspension of $10^{6}$ spores per $\mathrm{ml}$ of $P$. digitatum was prepared as previously described, and each fruit was inoculated by briefly immersing a steel probe with a 1 $\mathrm{mm}$ wide by $2 \mathrm{~mm}$ long tip into the spore suspension and immediately making a single wound on the equator of each fruit. After inoculation, the fruit were incubated for $24 \mathrm{~h}$ at 16 to $20^{\circ} \mathrm{C}$, and then four replicates of 25 fruit each were immersed in 22 liters of the treatment solutions for $2 \mathrm{~min}$ at $24^{\circ} \mathrm{C}\left( \pm 0.5^{\circ} \mathrm{C}\right)$. The following treatments were applied: (i) inoculated, untreated control, (ii) $\mathrm{NaHCO}_{3}$ (3\% wt/vol, $\mathrm{pH} 8.3$ ), (iii) $50,1,000,2,000$, or $4,000 \mu \mathrm{g} / \mathrm{ml}$ free chlorine at $\mathrm{pH} \mathrm{7.5,} \mathrm{and} \mathrm{(iv)} \mathrm{50,} \mathrm{1,000,}$ 2,000 , or $4,000 \mu \mathrm{g} / \mathrm{ml}$ free chlorine at $\mathrm{pH}$ 9.0. Each solution contained $20 \mathrm{mM}$ $\mathrm{Na}_{2} \mathrm{HPO}_{4}$ and the $\mathrm{pH}$ was adjusted with 1.0 $\mathrm{N} \mathrm{HCl}$ and $1.0 \mathrm{KOH}$ just before use. $\mathrm{NaOCl}$ concentrations were measured by DPD colorimetry and $\mathrm{pH}$ was measured with an electrode and neither changed during the experiment. Immediately after treatment, the fruit were rinsed briefly in fresh water and stored 1 week at $20^{\circ} \mathrm{C}$ before the occurrence of green mold was recorded. The experiment was conducted

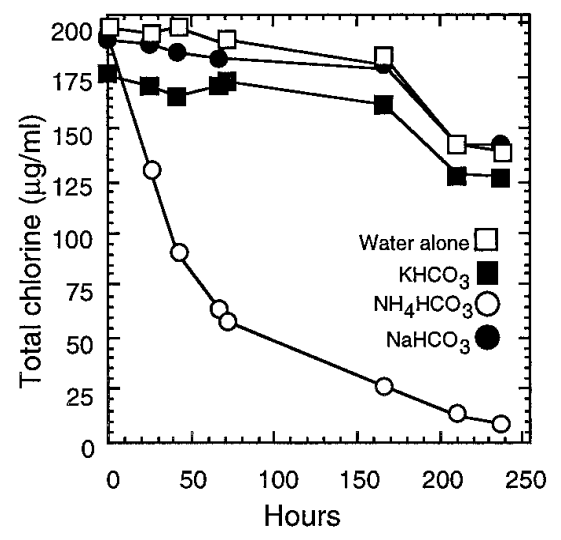

Fig. 1. The persistence of free chlorine in 0.5 $\mathrm{mM}$ bicarbonate salt solutions.

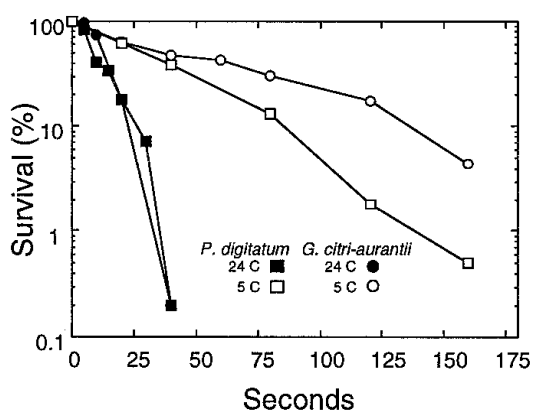

Fig. 2. Impact of temperature on the viability of spores of Penicillium digitatum and Geotrichum citri-aurantii in $200 \mu \mathrm{g}$ free chlorine $/ \mathrm{ml}$ in $3 \%(\mathrm{wt} / \mathrm{vol})$ sodium bicarbonate at $\mathrm{pH} 8.3$ at 5 and $24^{\circ} \mathrm{C}$. twice, once with oranges and once with lemons.

Statistical analysis. The influence of $\mathrm{pH}$ on the mortality of spores in $3 \% \mathrm{wt} / \mathrm{vol}$ $\mathrm{NaHCO} 3$ and $200 \mu \mathrm{g}$ free chlorine/ml was analyzed using Finney's probit analysis (26) to estimate the $\mathrm{LT}_{95}$ and $\mathrm{LT}_{99}$ values in seconds. The $\mathrm{LT}_{95}$ and $\mathrm{LT}_{99}$ values are the time in seconds when 95 or $99 \%$, respectively, of the spores were killed.

$\mathrm{LT}_{95}$ values and $95 \%$ confidence intervals were used to compare the rates of mortality of the fungi among $\mathrm{pH}$ levels. Concentration and time products were calculated by multiplying the $\mathrm{LT}_{95}$ and the $\mathrm{HOCl}$ concentration in $200 \mathrm{~g}$ chlorine/ml solutions. HOCL concentration was calculated using the actual $\mathrm{pH}$ of the solution, $\mathrm{pK}_{\mathrm{a}}$ of hypochlorous acid (7.5), and the Henderson-Hasselbach equation (31).

$\mathrm{LT}_{99}$ values were regressed against $\mathrm{pH}$ using the following model:

$$
L T_{99}=a b^{p H}
$$

The plots of the $\mathrm{LT}_{99}$ prediction curves included $95 \%$ confidence bands on the predictions. A model prediction of $\mathrm{LT}_{99}$ rather than $\mathrm{LT}_{95}$, was selected because this decrease in spore germinability, a 2-log reduction, would be more useable in practical packinghouse applications.

In tests to quantify the reduction in natural populations of yeasts and molds or spores of $P$. digitatum or $G$. citri-aurantii or in tests to control green mold, a one- to three-way analysis of variance (ANOVA) was applied followed by Fisher's Protected LSD $(P=0.05)$ to separate means (SuperANOVA, Abacus Concepts, Berkeley, CA). When the percentage of infected fruit was analyzed, ANOVA was applied to the square root of the arcsine of the proportion of infected fruit, and actual values are shown.

\section{RESULTS}

Compatibility of chlorine with bicarbonate salt solutions. Free chlorine persisted with little decline for 7 days in 0.5 $\mathrm{M} \mathrm{NaHCO}$ or $\mathrm{KHCO}_{3}$, but declined rapidly in $0.5 \mathrm{M} \mathrm{NH}_{4} \mathrm{HCO}_{3}$ (Fig. 1).

Impact of temperature on chlorine toxicity. Spores suspended in chlorine and $\mathrm{NaHCO}_{3}$ died much faster at 24 than $5^{\circ} \mathrm{C}$
(Fig. 2), and the impact of temperature was greater on $P$. digitatum than $G$. citriaurantii (Table 1). The $\mathrm{LT}_{95}$ of spores of $P$. digitatum in $200 \mu \mathrm{g}$ free chlorine/ml and $3 \% \mathrm{wt} / \mathrm{vol} \mathrm{NaHCO}_{3}, \mathrm{pH} 8.3$, at $24^{\circ} \mathrm{C}$ was $28.3 \mathrm{~s}$, while at $5^{\circ} \mathrm{C}$ in this solution the $\mathrm{LT}_{95}$ was $180 \mathrm{~s}$, a 6.4-fold increase in $\mathrm{LT}_{95}$. Under the same conditions, the $\mathrm{LT}_{95}$ for arthrospores of $G$. citri-aurantii at $24^{\circ} \mathrm{C}$ was $31.0 \mathrm{~s}$, while at $5^{\circ} \mathrm{C}$ it was $108 \mathrm{~s}$, a 3.5-fold increase in $\mathrm{LT}_{95}$.

Impact of $\mathbf{p H}$ on chlorine toxicity. The $\mathrm{pH}$ of the $\mathrm{NaHCO}_{3}(3 \% \mathrm{wt} / \mathrm{vol})$ and chlorine $(200 \mu \mathrm{g} / \mathrm{ml})$ solution greatly influenced its activity towards spores suspended in the solution (Fig. 3). Spores died more slowly when the $\mathrm{pH}$ of the solution increased from 7 to 10 , and the impact of $\mathrm{pH}$ was greater on $G$. citri-aurantii than $P$. digitatum (Table 1). The concentration $\times$ time product associated with the $\mathrm{LT}_{95}$ at each solution $\mathrm{pH}$, the product of the calculated $\mathrm{HOCl}$ concentration multiplied by the $\mathrm{LT}_{95}(\mu \mathrm{g} / \mathrm{ml} * \mathrm{~s})$, was not constant and declined as $\mathrm{pH}$ increased above 8 (Table 2).

Chlorine toxicity models. A model that estimated a 2- $\log _{10}\left(\mathrm{LT}_{99}\right)$ mortality in seconds at $24^{\circ} \mathrm{C}$ from $\mathrm{pH} 7$ to 10 for $P$. digitatum spores was: $\mathrm{LT}_{99}=0.212(1.88)^{\mathrm{pH}}$ (Fig. 4). Solutions at pH 7.0, 8.0, 8.3, 9.0, and 10.0 for the $\mathrm{LT}_{99}$ of spores of $P$. digitatum were $18.3,32.8,64.3$, and $120 \mathrm{~s}$, respectively. A model that estimated a $2-$ $\log \left(\mathrm{LT}_{99}\right)$ mortality in seconds at $24^{\circ} \mathrm{C}$ from $\mathrm{pH} 7$ to 10 for G. citri-aurantii arthrospores was; $\mathrm{LT}_{99}=0.000004 .98$ $(6.18)^{\mathrm{pH}}$ (Fig. 4). Solutions at $\mathrm{pH} 7.0,8.0$, 8.3, 9.0, and 10.0 for the $\mathrm{LT}_{99}$ of arthrospores of $G$. citri-aurantii were 3.4, 15.6, 63.3, and $402 \mathrm{~s}$, respectively.

Impact of chlorine treatment on the viability of spores and natural microbe populations. Immersion of lemons for 1 $\min$ at $24^{\circ} \mathrm{C}$ in $200 \mu \mathrm{g}$ free chlorine $/ \mathrm{ml}$, alone or with $3 \% \mathrm{wt} / \mathrm{vol} \mathrm{NaHCO}_{3}$, both at $\mathrm{pH}$ 7.7, reduced the number of viable spores of $P$. digitatum and $G$. citri-aurantii from approximately $10^{6}$ to $10^{3}$ spores per fruit (Fig. 5). Natural yeast and mold populations were significantly $(P>0.001)$ more resistant to 50 and $200 \mu \mathrm{g}$ chlorine $/ \mathrm{ml}$ than $P$. digitatum or $G$. citri-aurantii and reduced from approximately $10^{6}$ to $10^{4}$

Table 1. The time in seconds when $95 \%$ of the spores $\left(\mathrm{LT}_{95}\right)$ of Penicillium digitatum and arthrospores of Geotrichum citri-aurantii died in $200 \mu \mathrm{g}$ free chlorine per $\mathrm{ml}$ and $\mathrm{NaHCO}_{3}(3 \% \mathrm{wt} / \mathrm{vol})$ at 5 and $24^{\circ} \mathrm{C}^{\mathrm{z}}$

\begin{tabular}{|c|c|c|c|c|c|c|c|}
\hline \multirow[b]{3}{*}{ pH } & \multirow[b]{3}{*}{$\operatorname{Temp}\left({ }^{\circ} \mathbf{C}\right)$} & \multicolumn{3}{|c|}{ P. digitatum } & \multicolumn{3}{|c|}{ G. citri-aurantii } \\
\hline & & \multicolumn{3}{|c|}{$95 \% \mathrm{CI}$} & \multicolumn{3}{|c|}{$95 \% \mathrm{CI}$} \\
\hline & & $\mathbf{L T}_{\mathbf{9 5}}$ & Lower & Upper & $\mathbf{L T}_{\mathbf{9 5}}$ & Lower & Upper \\
\hline 7.0 & 24.0 & 13.2 & 11.7 & 16.8 & 3.0 & 2.5 & 4.1 \\
\hline 8.0 & 24.0 & 19.1 & 16.3 & 25.1 & 12.6 & 10.1 & 19.1 \\
\hline 9.0 & 24.0 & 29.4 & 24.3 & 42.7 & 56.6 & 51.9 & 68.8 \\
\hline 10.0 & 24.0 & 88.4 & 77.8 & 108.3 & 114.0 & 100.0 & 154.0 \\
\hline 8.3 & 24.0 & 28.3 & 24.7 & 33.9 & 31.0 & 25.0 & 42.8 \\
\hline 8.3 & 5.0 & 180.2 & 149.1 & 250.5 & 108.4 & 91.0 & 136.9 \\
\hline
\end{tabular}

${ }^{\mathrm{z}}$ The $\mathrm{LT}_{95}$ and $95 \%$ confidence intervals $(\mathrm{CI})$ were determined by probit analysis. 
CFU/fruit by this treatment. Free chlorine at $50 \mu \mathrm{g} / \mathrm{ml}$ was significantly (paired $t$ test; $P=0.0495$ ) less effective than at 200 $\mu \mathrm{g} / \mathrm{ml}$. Treatment with water or $\mathrm{NaHCO}_{3}$ alone did not reduce spore or microbe populations, and the presence of $\mathrm{NaHCO}_{3}$ had no significant influence on chlorine efficacy.

Green mold on inoculated lemons and oranges after immersion in chlorine or $\mathrm{NaHCO}_{3}$ solutions. Green mold occurrence was reduced more than $90 \%$ on lemons and oranges by immersion in $\mathrm{NaHCO}_{3}$ ( $3 \% \mathrm{wt} / \mathrm{vol}$ ), while immersion in chlorine alone at concentrations as high as 4,000 $\mu \mathrm{g} / \mathrm{ml}$ reduced green mold no more than $40 \%$ (Table 3). Chlorine efficacy was generally similar at 1,000 to $4,000 \mu \mathrm{g}$ per $\mathrm{ml}$ and significantly superior to $50 \mu \mathrm{g}$ per $\mathrm{ml}$. Efficacy was similar at $\mathrm{pH} 7$ and 9. The fruit were not visibly harmed by these treatments.

\section{DISCUSSION}

The toxicity of aqueous chlorine was substantially influenced by temperature and the magnitude of the increase in toxicity was similar to that reported for other microbes. A temperature increase from 5 to $24^{\circ} \mathrm{C}$ of the chlorinated bicarbonate solution increased the rate of mortality of $P$. digitatum and $G$. citri-aurantii by factors of 6.4 and 3.5, respectively. Phillips and Grendahl (22) reported that the percentage of spores of Monilinia fructicola that survived $5 \mathrm{~min}$ exposure in $3 \mu \mathrm{g} / \mathrm{ml}$ chlorine

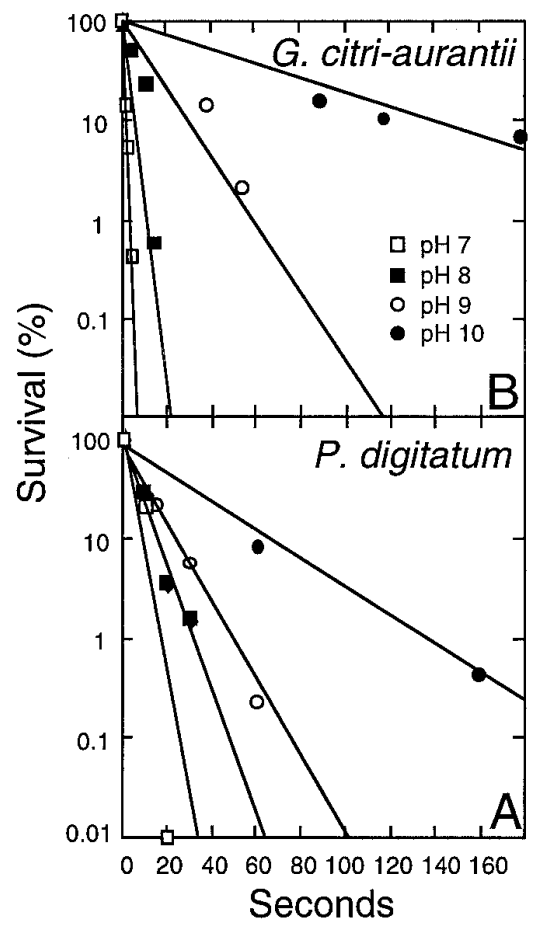

Fig. 3. Viability of spores of Penicillium digitatum $\mathbf{A}$, and Geotrichum citri-aurantii $\mathbf{B}$, in $200 \mu \mathrm{g}$ free chlorine/ml and $3 \%(\mathrm{wt} / \mathrm{vol}) \mathrm{Na}-$ $\mathrm{HCO}_{3}$ at $\mathrm{pH} 7,8,9$, or 10. at $0,5,10,15,20$, and $25^{\circ} \mathrm{C}$ was 95,90 , $80,60,32$, and 2 , respectively. Kostenbauder (17) reported that a temperature coefficient, termed $\mathrm{Q}_{10}$, described the increase in the rate of mortality of many microorganisms in many toxicants for each $10^{\circ} \mathrm{C}$ rise in temperature. It is analogous to the impact of temperature on the first order rate constant of simple chemical reactions. In reviews by Dychdala (7) and Hoff (13), the $\mathrm{Q}_{10}$ for many microorganisms in chlorine was 2 to 3 until the rise was sufficient that thermal destruction began to occur. The $\mathrm{Q}_{10}$ for $P$. digitatum and $G$. citriaurantii we observed was 3.4 and 1.8, respectively.

The toxicity of aqueous chlorine was also substantially influenced by $\mathrm{pH}$ and the magnitude of effect on toxicity was similar to that reported for other microbes. In our work, a 1.5- to 4-fold decrease in chlorine potency occurred for every unit of $\mathrm{pH}$ increase from 7 to 10. Brown and Wardowski (5) reported that chlorine at $100 \mu \mathrm{g} / \mathrm{ml}$ at pH 7 killed $P$. digitatum and G. citriaurantii spores within $10 \mathrm{~s}$, while at $\mathrm{pH} 9$, the chlorine concentration had to be doubled to kill all the spores within $10 \mathrm{~s}$. In their work, they observed the germination of spores on agar media $24 \mathrm{~h}$ after treatment, while we counted colonies of these fungi that developed 5 days after treatment. In preliminary tests, we found observation of spore's germination on media overestimated chlorine toxicity, because the germination of many spores was delayed rather than stopped. This difference in the determination of spore germinability might explain the greater chlorine potency they observed than we did in this study. Robbs et al. (24) reported that a 2-log reduction in the viability of arthrospores of $G$. candidum in 2 min required 11,14 , and $25 \mu \mathrm{g}$ free chlorine/ml at $\mathrm{pH} 6,7$, and 8 , respectively. Segall (27) found that the rate of mortality of spores of Alternaria tenuis in $3 \mu \mathrm{g} / \mathrm{ml}$ chlorine was similar at $\mathrm{pH} 6$ to 7.5 and only slightly reduced at $\mathrm{pH} 8$. Rudolph and Levine (25) reported that for Bacillus metiens in $25 \mu \mathrm{g} / \mathrm{ml}$ chlorine, they observed an average decrease of toxicity of 3.4-fold for each unit of increase in $\mathrm{pH}$ between $\mathrm{pH} 7$ and 13. Granum and Magnussen (11) evaluated chlorine toxicity to Escherichia coli, Staphylococcus aureus, Pseudomonas aeruginosa, Saccharomyces cerevisiae, and spores of $B$. subtilis from $\mathrm{pH} 5$ to 9 and concluded that hypochlorite potency decreased by a factor of 2.5 for each unit of $\mathrm{pH}$ increase from 5 to 8 , and by a factor of 6 from 8 to 9 .

While the rate of spore mortality decreased as $\mathrm{pH}$ increased, it occurred much faster at high $\mathrm{pH}$ than would be expected if chlorine toxicity were entirely due to calculated hypochlorous acid content present in the solution. If the sole toxic component were hypochlorous acid, a 10-fold decrease in chlorine toxicity would be expected with each unit of $\mathrm{pH}$ increase above the dissociation constant (about $\mathrm{pH}$ 7.5) for chlorine. This interpretation overestimates the influence of $\mathrm{pH}$ on chlorine toxicity observed in our work and other empirical studies. Chlorine toxicity would be proportional to the product of exposure period and hypochlorous acid content. In our work, the product of the $\mathrm{HOCl}$ concentration and $\mathrm{LT}_{95}(\mu \mathrm{g} / \mathrm{ml} * \mathrm{~s})$ was not constant and declined as $\mathrm{pH}$ increased above $\mathrm{pH} 8$ (Table 2). This result suggests that other factors such as the hypochlorite ion, are contributing to chlorine toxicity. Hadfield (12) stated that as hypochlorous acid is consumed during disinfection, protonation of the hypochlorite ion will occur and hypochlorous acid will be continuously produced, a phenomenon termed the "reservoir effect". Potency of the chlorine solution depends on the amount of $\mathrm{HOCl}$ absorbed by the microbe. At lower $\mathrm{pH}$, a large portion of chlorine is in this form and mortality is more rapid, while at higher $\mathrm{pH}$ the $\mathrm{HOCl}$ is elaborated more slowly by its equilibrium with $\mathrm{OCl}^{-}$ion and mortality occurs more slowly. Another interpretation is that hypochlorite ion itself has toxicity, from 20 to 300 times less than hypochlorous acid, depending on the microorganism (31). In our work, $P$. digitatum died much more rapidly in high $\mathrm{pH}$ chlorine solutions than $G$. citri-aurantii, so $P$. digitatum was more sensitive to hypochlorite ion. The contribution of hypochlorite ion to toxicity increases when contact times are long (12) or when the chlorine solution is cool (31).

In this work, we assumed the dissociation constant $\left(\mathrm{pK}_{\mathrm{a}}\right)$ of chlorine was 7.5. However, the $\mathrm{pK}_{\mathrm{a}}$ of chlorine is moderately influenced by temperature and ionic strength of the chlorine solution (31). The $\mathrm{pH}$ of the dissociation constant $\left(\mathrm{pK}_{\mathrm{a}}\right)$ of chlorine shifts downward as temperature increases, which reduces the hypochlorous acid content of the solution. By the method of Morris (18), at $5^{\circ} \mathrm{C}$ the $\mathrm{pK}_{\mathrm{a}}$ of hypochlo-

Table 2. Calculated concentrations $(\mu \mathrm{g} / \mathrm{ml})$ of $\mathrm{HOCl}$ and $\mathrm{OCl}^{-}$at $\mathrm{pH} 7,8,9$, and 10 in $\mathrm{NaHCO}_{3}(3 \%$ $\mathrm{wt} / \mathrm{vol}$ ) and $200 \mu \mathrm{g} / \mathrm{ml}$ free chlorine $\left(\mathrm{HOCl}+\mathrm{OCl}^{2}\right.$ ) at $24^{\circ} \mathrm{C}, \mathrm{LT}_{95}$ in seconds of spores of Penicillium digitatum and arthrospores of Geotrichum citri-aurantii, and the product of $\mathrm{HOCl}$ concentration and $\mathrm{LT}_{95}(\mu \mathrm{g} / \mathrm{ml} * \mathrm{~s})$

\begin{tabular}{rrrrrrrr}
\hline & & & \multicolumn{2}{c}{ P. digitatum } & & \multicolumn{2}{c}{ G. citri-aurantii } \\
$\mathbf{n n n n n n n}$ & HOCl & OCl & $\mathbf{L T}_{\mathbf{9 5}}$ & $\mathbf{L T}_{\mathbf{9 5}} \times \mathbf{H O C l}$ & $\mathbf{L T}_{\mathbf{9 5}}$ & $\mathbf{L T}_{\mathbf{9 5}} \times \mathbf{H O C l}$ \\
\hline 7.0 & 152.0 & 48.0 & 13.2 & 33.4 & 3.0 & 7.6 \\
8.0 & 48.1 & 151.9 & 19.1 & 15.3 & & 12.6 & 10.1 \\
9.0 & 6.1 & 193.9 & 29.4 & 12.9 & & 56.6 & 5.8 \\
10.0 & 0.6 & 199.4 & 88.4 & 0.9 & & 114.0 & 1.1 \\
\hline
\end{tabular}


rite in water is 7.76 , while at $24^{\circ} \mathrm{C}$ it is 7.55. Increasing ionic strength reduces the $\mathrm{pK}_{\mathrm{a}}$ of chlorine, and sodium bicarbonate at $3 \% \mathrm{wt} / \mathrm{vol}$ would reduce the $\mathrm{pK}_{\mathrm{a}}$ moderately. White (31) addressed both the impact of temperature and ionic strength on the $\mathrm{pK}_{\mathrm{a}}$ of chlorine. At $25^{\circ} \mathrm{C}$, the $\mathrm{pK}_{\mathrm{a}}$ of chlo-

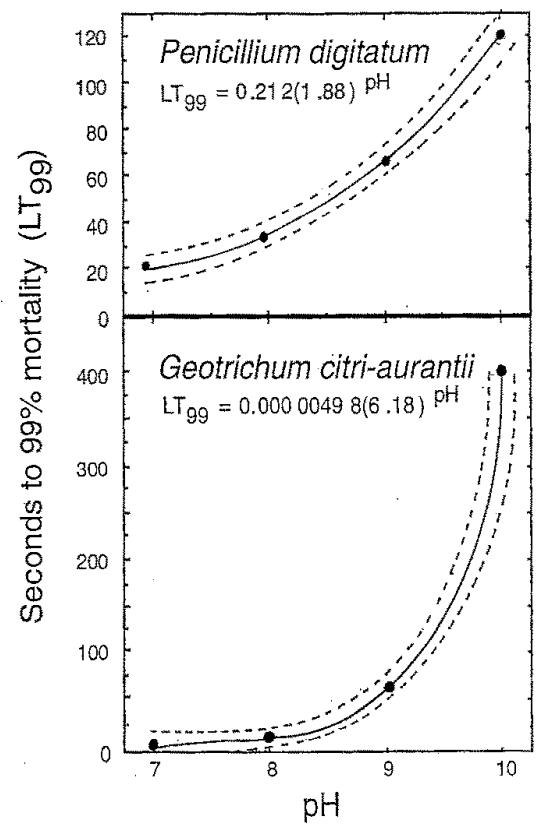

Fig. 4. Models predicting seconds to $99 \%$ mortality $\left(\mathrm{LT}_{99}, \pm 95 \%\right.$ confidence interval) of spores of Geotrichum citri-aurantii and Penicillium digitatum in $200 \mu \mathrm{g}$ free chlorine/ml and 3\% (wt/vol) $\mathrm{NaHCO}_{3}$ at pH 7, 8, 9, or 10 .

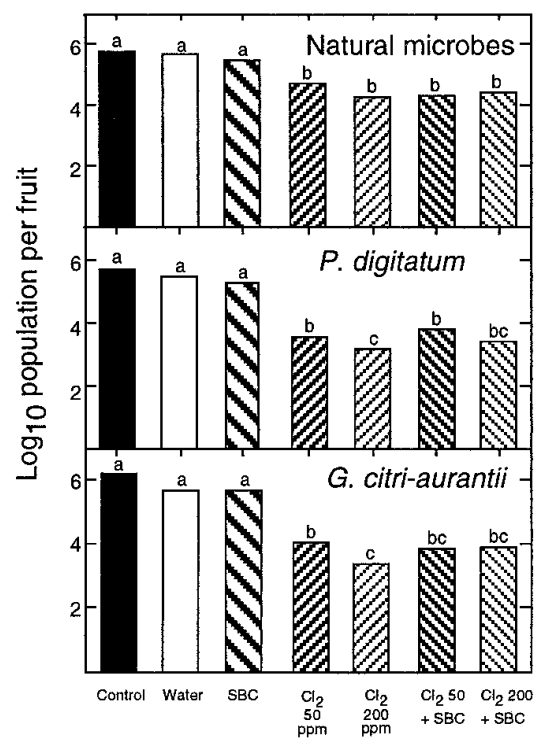

Fig. 5. Populations of natural yeasts and molds, or viable spores of Penicillium digitatum or Geotrichum citri-aurantii on lemon fruit after immersion $1 \mathrm{~min}$ in water, 50 or $200 \mu \mathrm{g}$ free chlorine/ml, $\mathrm{NaHCO}_{3}(\mathrm{SBC})$, or 50 or $200 \mu \mathrm{g}$ free chlorine/ml with $3 \%$ wt/vol $\mathrm{NaHCO}_{3}$. Columns within each class of organism with unlike letters differ significantly by Fisher's $\operatorname{LSD}(P=0.05)$. rine declined from 7.5 to 7.1 in an idealized $4 \% \mathrm{wt} / \mathrm{vol}$ salt solution, while at $5^{\circ} \mathrm{C}$, the $\mathrm{pK}_{\mathrm{a}}$ of chlorine declined from 7.8 to 7.3 in this solution. Therefore, at $\mathrm{pH} 8.3$, in this salt solution, hypochlorous acid content at $25^{\circ} \mathrm{C}$ is $6.0 \%$, while at $5^{\circ} \mathrm{C}$ it is $2.0 \%$. Therefore, the increase in chlorine toxicity expected by temperature impact on reaction rate is moderated by the decrease in $\mathrm{pK}_{\mathrm{a}}$ caused by temperature, which reduces hypochlorous acid content. A further complexity is the influence of temperature on the $\mathrm{pK}_{\mathrm{a}}$ and subsequent ionic strength of the carbonate and bicarbonate ions. As temperature increases, the $\mathrm{pK}_{\mathrm{a}}$ of the bicarbonate-carbonate equilibrium will decrease from 10.2 and carbonate, a bivalent anion that contributes twice the ionic strength of the monovalent bicarbonate anion, will increase. Carbonate ion concentration increases at higher $\mathrm{pH}$, and this increase in ionic strength reduces the $\mathrm{pK}_{\mathrm{a}}$ of chlorine, which reduces the proportion of hypochlorous acid. The influence of these factors on chlorine toxicity was probably too modest to be detected in our study. For example, the magnitude of the reductions in populations of spores and microbes on lemon fruit surfaces was similar whether sodium bicarbonate was present or not (Fig. 5).

In citrus packinglines, the residence time of fruit in chlorinated dump tanks or bicarbonate solutions should be of sufficient length to kill spores in the water and on the fruit. Prolonging the contact period also improves control of green mold by sodium bicarbonate (29). If spores that emerge at the end of the packingline tanks, belts, or brush beds are alive, where subsequent rinse water could rescue them from additional chlorine contact, they could contaminate subsequent processing steps and increase decay incidence. A residence time of $2 \mathrm{~min}$ in water or sodium bicarbonate containing $200 \mu \mathrm{g}$ free chlorine per $\mathrm{ml}$ is sufficient to kill $99 \%$ or more of the spores of $P$. digitatum and $G$. citri-aurantii, even if the $\mathrm{pH}$ of the solution is as high as 9 . Surface populations of spores of these pathogens and natural yeasts and molds should also be reduced similarly.
We observed natural yeasts and molds on fruit surfaces were reduced about $2 \operatorname{logs}$ by immersion in 50 or $200 \mu \mathrm{g}$ chlorine $/ \mathrm{ml}$, while spores of $P$. digitatum and $G$. citriaurantii were reduced about $3 \operatorname{logs}$ by this treatment. The reductions we observed when the fruit were immersed in the chlorine solutions were greater than reported in prior reports when these solutions were sprayed on fruit. We have repeatedly observed that the immersion of fruit into fungicides or sanitizers is superior to spraying the solutions over rotating brushes (28). Brown and Wardowski (5) reported that while a $15 \mathrm{~s}$ spray on oranges with up to $1,000 \mu \mathrm{g}$ chlorine/ml killed all of the spores of $P$. digitatum, it reduced those of $G$. citri-aurantii only by approximately 50\%. Pao and Brown (20) reported commercial washing with either water alone or $200 \mu \mathrm{g}$ chlorine $/ \mathrm{ml}$ sprayed over rotating brushes reduced yeast and mold counts similarly and only about $1 \log$.

The cycling period of chlorinated water or sodium bicarbonate through pressure washing systems, dump tanks, or drenches should be of sufficient duration that spores are killed during this cycle before they can contact fruit. For example, if a solution of $3 \% \mathrm{NaHCO}_{3}$ and $200 \mu \mathrm{g}$ free chlorine/ml at $\mathrm{pH} 9$ was in use in a drencher and if each cycle of passage of the solution through the system was $15 \mathrm{~s}$, only about $50 \%$ of the spores of $P$. digitatum would have been killed in this brief cycle and many viable spores could be applied to the fruit. If a retention time of $2 \mathrm{~min}$ was employed, perhaps by the addition of an accumulation tank to prolong the contact period of the spores to chlorine before the water is reapplied, $99 \%$ or more of the spores of $P$. digitatum and $G$. citri-aurantii would be killed, even if the solution $\mathrm{pH}$ was as high as 9 .

In this work, only freshly prepared chlorine solutions in water or sodium bicarbonate were used, while solutions used in citrus packinghouses can become turbid and contaminated with soil and fruit constituents. The impact of these changes on the toxicity of chlorinated solutions in packinghouses deserves additional study be-

Table 3. Green mold between lemons and oranges wound-inoculated with spores of Penicillium digitatum $24 \mathrm{~h}$ before treatment by immersion in the solutions for $2 \mathrm{~min}$ followed by storage at $20^{\circ} \mathrm{C}$ for 1 week

\begin{tabular}{|c|c|c|c|c|}
\hline \multirow[b]{3}{*}{ Treatment } & \multicolumn{4}{|c|}{ Green mold occurrence $(\%)^{y}$} \\
\hline & \multicolumn{2}{|c|}{ Oranges } & \multicolumn{2}{|c|}{ Lemons } \\
\hline & pH 7.0 & pH 9.0 & pH 7.0 & pH 9.0 \\
\hline Untreated control & $100.0 \mathrm{a}$ & $95.0 \mathrm{a}$ & $100.0 \mathrm{a}$ & $100.0 \mathrm{a}$ \\
\hline Water alone & $97.0 \mathrm{a}$ & $88.0 \mathrm{~b}$ & $100.0 \mathrm{a}$ & $100.0 \mathrm{a}$ \\
\hline $50 \mu \mathrm{g} / \mathrm{ml}$ chlorine & $98.0 \mathrm{a}$ & $92.0 \mathrm{ab}$ & $93.3 \mathrm{a}$ & $92.8 \mathrm{ab}$ \\
\hline $1,000 \mu \mathrm{g} / \mathrm{ml}$ chlorine & $75.0 \mathrm{~b}$ & $74.0 \mathrm{c}$ & $64.0 \mathrm{~b}$ & $62.8 \mathrm{c}$ \\
\hline $2,000 \mu \mathrm{g} / \mathrm{ml}$ chlorine & $82.0 \mathrm{~b}$ & $59.0 \mathrm{~d}$ & $66.3 \mathrm{~b}$ & $76.8 \mathrm{~b}$ \\
\hline $4,000 \mu \mathrm{g} / \mathrm{ml}$ chlorine & $79.0 \mathrm{~b}$ & $59.0 \mathrm{~d}$ & $65.0 \mathrm{~b}$ & $70.0 \mathrm{~b}$ \\
\hline $\mathrm{NaHCO}_{3}(3 \% \text { wt vol })^{\mathrm{z}}$ & $7.0 \mathrm{c}$ & $7.0 \mathrm{e}$ & $8.0 \mathrm{c}$ & $8.0 \mathrm{~d}$ \\
\hline
\end{tabular}

y Values followed by unlike letters differ significantly $(P \leq 0.05)$ according to Fisher's Protected LSD.

${ }^{\mathrm{z}}$ The $\mathrm{pH}$ of $\mathrm{NaHCO}_{3}$ solution was 8.3. 
cause it could be significant. The efficacy of chlorine used for water disinfection declines as turbidity increases (31). Free chlorine declines and is usually replenished automatically or manually as process water is used in citrus packinghouses. Free chlorine becomes bound or is reduced to chloride. Amines, from ammonia, proteins, and other nitrogen-containing organic substances, will react with chlorine to form the "nuisance disinfectants" of nitrogen trichloride and less toxic or nontoxic chloramines (7). Our result that free chlorine did not persist in an ammonium bicarbonate solution was probably a result of the formation of these compounds. Nitrogen trichloride is very toxic to fungi and this gas was once employed to control postharvest decay of citrus fruit (15). Among the nuisance disinfectants, only nitrogen trichloride gas causes irritation to workers' eyes (31), a common complaint among packinghouse personnel near chlorine solutions. To determine if organic nitrogen significantly interferes with chlorination efficiency as the solutions age, the amount of nitrogen available to react with chlorine could be determined (31). If the ammonia to chlorine ratio exceeds $1: 5$ and chlorine continues to accumulate, the chloramines are oxidized and destroyed by additional chlorine, and free chlorine can now increase readily (7). Other constituents released from the fruit, such as starches, lipids, alcohols, and sugars, should have little effect on the germicidal activity of chlorine. If the ionic strength of the solutions increases as they age, this would impact the $\mathrm{pK}_{\mathrm{a}}$ of chlorine as previously discussed and decrease chlorine toxicity (7). However, simple observations in packinghouses that we have done, suggest that chlorination under commercial conditions is at least approximately as effective as we describe it here. For example, we found that viable spores of $P$. digitatum were present in packinghouse tanks containing $200 \mu \mathrm{g}$ free chlorine per $\mathrm{ml}$ and $3 \% \mathrm{Na}-$ $\mathrm{HCO}_{3}$ while large numbers of fruit were passing through the tanks, but none could be found several minutes after they had passed out of the tank.

Immersion of inoculated fruit in chlorine solutions alone, even at concentrations as high as $4,000 \mu \mathrm{g}$ free chlorine per $\mathrm{ml}$, did not cause a useful reduction in the subsequent green mold and was inferior to immersion in $\mathrm{NaHCO}_{3}$ for this purpose. D'Aquino et al. (6) similarly reported that immersion of minneola tangelos in $500 \mu \mathrm{g}$ free chlorine per $\mathrm{ml}$ for $2 \mathrm{~min}$ did not reduce subsequent green mold, significantly increased ethylene production and respiration rate, and that the treated fruit aged more rapidly. We found that adjusting the chlorine solution $\mathrm{pH}$ had no impact on its ability to control green mold. Granum and Magnussen (11) stated that since chlorine stability increases at higher $\mathrm{pH}$, optimal disinfection of the surfaces of fresh products might occur at higher $\mathrm{pH}$ than is optimal for chlorine toxicity. We did not see evidence of improved penetration at higher $\mathrm{pH}$; chlorine was presumably too reactive to penetrate into the wounds where the spores resided. Although incapable of controlling inoculum in wounds, immersion of fruit in high concentrations of chlorine dramatically reduced surface populations of $P$. digitatum and G. citri-aurantii, and substantially reduced natural yeast and mold populations.

\section{ACKNOWLEDGMENTS}

We thank the California Citrus Research Board for financial support, and acknowledge the technical assistance of E. Kaneshiro, M. W. Morris, and M. M. Morris.

\section{LITERATURE CITED}

1. Anonymous. 1998. Method 4500-CI G. DPD colorimetric method. Section 4, pages 63-64 in: Standard Methods for the Examination of Water and Wastewater. L. S. Clesceri, A. E. Greenberg, and A. D. Eaton, eds. American Public Health Association, Washington D.C.

2. Barger, W. R. 1928. Sodium bicarbonate as a citrus fruit disinfectant. Calif. Citrogr. 13:164-174.

3. Beattie, B., Wild, B., Tugwell, B., Bagshaw, J., and Keenan, P. 1992. Postharvest. Pages 122-184 in: Guide to Quality Management in the Citrus Industry. B. Beattie and L. Revelant, eds. Australian Horticultural Corporation, Sydney, Australia.

4. Brown, G. E., and Miller, W. R. 1999. Maintaining fruit health after harvest. Pages 175198 in: Citrus Health Management. L. W. Timmer and L. W. Duncan, eds. American Phytopathological Society, St. Paul MN.

5. Brown, G. E., and Wardowski, W. F. 1984. Use of chlorine and chlorine dioxide in Florida citrus packinghouses to reduce inoculum of decay pathogens. Proc. Fla. State Hortic. Soc. 97:97-100.

6. D'Aquino, S., Piga, A., Agabbio, M., and McCollum, T. G. 1998. Film wrapping delays ageing of "Minneola" tangelos under shelflife conditions. Postharvest Biol. Technol. 14:107-116.

7. Dychdala, G. R. 1991. Chlorine and chlorine compounds. Pages131-151 in: Disinfection, Sterilization, and Preservation. S. S. Block, ed. Lea and Febiger, Philadelphia.

8. Eckert, J. W., and Brown, G. E. 1986. Evaluation of postharvest treatments for citrus fruits. Pages 92-97 in: Methods for Evaluating Pesticides for Control of Plant Pathogens. K. D. Hickey, ed. American Phytopathological Society, St. Paul, MN.

9. Eckert, J. W., and Eaks, I. L. 1989. Postharvest disorders and diseases of citrus fruits. Pages 179-260 in: The Citrus Industry. Vol. 4. W. Reuther, E. C. Calavan, and G. E. Carman, eds. University of California Press, Berkeley.

10. Fawcett, H. S. 1936. Citrus diseases and their control. 2nd ed. McGraw Hill, New York.

11. Granum, P. E., and Magnussen, J. 1987. The effect of $\mathrm{pH}$ on hypochlorite as a disinfectant. Int. J. Food Microbiol. 4:183-186.

12. Hadfield, W. A. 1957. Chlorine and chlorine compounds. Pages 558-580 in: Antiseptics,
Disinfectants, Fungicides, and Chemical and Physical Sterilization. J. F. Redish, ed. Lea and Febiger, Philadelphia.

13. Hoff, J. C. 1986. Inactivation of microbial agents by chemical disinfectants. United States Environmental Protection Agency Technical Report EPA/600/2-86/067.

14. Hwang, L. and Klotz, L. J. 1938 The toxic effects of certain chemical solutions on spores of Penicillium italicum and P. digitatum. Hilgardia 12:1-15.

15. Klotz, L. J. 1936. Nitrogen trichloride and other gases as fungicides. Hilgardia 10:27-52.

16. Klotz, L. J. 1973. Color handbook of citrus diseases. University of California, Berkeley.

17. Kostenbauder, H. B. 1991. Physical factors influencing the activity of antimicrobial agents. Pages 59-71 in: Disinfection, Sterilization, and Preservation. 4th ed. S. S. Block, ed. Lea and Febiger, Philadelphia.

18. Morris, J. C. 1966. The acid ionization constant of $\mathrm{HOCl}$ from 5 to $35^{\circ} \mathrm{C}$. J. Phys. Chem. 70:3798-3804.

19. Palou, L., Smilanick, J. L., Usall, J., and Viñas, I. 2001. Control of postharvest blue mold of oranges by hot water, sodium carbonate, and sodium bicarbonate. Plant Dis. 85:371-376.

20. Pao, S., and Brown, G. E. 1998. Reduction in microorganisms on citrus fruit surfaces suring packinghouse processing. J. Food Prot 61:903-906.

21. Pelser, P. duT. 1977. Postharvest handling of South African citrus fruit. Proc. Int. Soc. Citriculture 1:244-249.

22. Phillips, D. J., and Grendahl, J. 1973. The effect of chlorinating hydrocooling water on Monilinia fructicola conidia and brown rot. Plant Dis. Rep. 57:814-816.

23. Ritenour, M. A., Sargent, S. A., and Bartz, J. A. 2000. Chlorine use in citrus packinghouses. Packinghouse Newsletter 192:4-6.

24. Robbs, P. G., Bartz, J. A., Brecht, J. K., and Sargent, S. A. 1995. Oxidation-reduction potential of chlorine solutions and their toxicity to Erwinia carotovora subsp. carotovora and Geotrichum candidum. Plant Dis. 79:158-162.

25. Rudolph A. S., and Levine, M. 1941. Factors affecting the germicidal efficiency of hypochlorite solutions. Bull. 150, Eng. Exp. Sta., Iowa State College.

26. SAS Institute. 1989. SAS/STAT User's Guide, version 6, 4th ed., vol 2. Cary, NC, SAS Institute, Inc.

27. Segall, R. H. 1968. Fungicidal effectiveness of chlorine as influenced by concentration, temperature, $\mathrm{pH}$, and spore exposure time. Phytopathology 58:1412-1414.

28. Smilanick, J. L., Mackey, B. E., Reese, R., Usall, J., and Margosan, D. A. 1997. Influence of the concentration of soda ash, temperature, and immersion period on the control of postharvest green mold of oranges. Plant Dis. 81:379-382.

29. Smilanick, J. L., Margosan, D. A., Mlikota, F., Usall, J., and Michael, I. F. 1999. Control of citrus green mold by carbonate and bicarbonate salts and the influence of commercial postharvest practices on their efficacy. Plant Dis. 83:139-145.

30. Sorenson, D., Smilanick, J. L., and Margosan, D. A. 1999. Postharvest high pressure washing of citrus fruit with sodium bicarbonate to control green mold. (Abstr.) Phytopathology 89:S74

31. White, G. C. 1999. Handbook of chlorination and alternative disinfectants. 4th ed. WileyInterscience, New York. 